\title{
Morphological Variability of Breadfruit Tree (Artocarpus altilis) in Benin
}

\author{
Karl Tamègnon Assogba ${ }^{1 *}$, Célestin C.K. Tchekessi ${ }^{1}$, Roseline Bleoussi ${ }^{1}$, \\ Pivot S.A. Sachi ${ }^{1}$, Anayce A. Djogbe ${ }^{1}$, Jultesse S.B. Banon ${ }^{1}$, Innocent Bokossa Yaou ${ }^{1}$ \\ and Paulin Azokpota ${ }^{2}$
}

${ }^{1}$ Food Safety Research Unit (URSSA), Laboratory of Microbiology and Food Technologies (LAMITA), Department of Plant Biology, Faculty of Science and Technology (FAST), University of Abomey-Calavi (UAC), O1BP 4521, Cotonou, Republic of Benin

${ }^{2}$ Food Sciences Laboratory (LSA), Laboratory of Food Formulations and Molecular Biology (LAFAB); Department of Nutrition, Food Science and Technology, Faculty of Agricultural Sciences (FSA), University of Abomey-Calavi (UAC), 02 BP 2810, Cotonou, Republic of Benin

*Corresponding author

\begin{tabular}{|l|}
\hline K e y w o r d s \\
$\begin{array}{l}\text { Morphological } \\
\text { descriptors, fruits, leaves, } \\
\text { Artocarpus altilis, Benin }\end{array}$ \\
\hline Article Info \\
\hline $\begin{array}{l}\text { Accepted: } \\
\text { 20 December } 2018 \\
\text { Available Online: } \\
\text { 10 January } 2019\end{array}$ \\
\hline
\end{tabular}

The breadfruit tree (Artocarpus altilis), despite its food, therapeutic and agroforestry potential, remained underutilized in Benin due to the lack of information on the species. The objective of this study is to carry out the morphological characterization of the species in order to have a better knowledge of its diversity in Benin, an essential step in its safeguarding and its use. Thus, the discriminatory morphological descriptors in Artocarpus altilis in relation to the agro-ecological diversity of Benin have been identified. Foliar, fruit and seed characteristics were studied. The study areas concerned were the communes of Adjohoun, Avrankou, Dangbo and Adja-Ouèrè spread over the entire geographical range of the breadfruit in Benin. The results obtained showed a significant significance of the variables observed according to the provenances and the descriptors used (the shape of the fruit, the texture of the skin of the fruit, the color of the flesh of the fruit, the number of lobes and the degree of dissection of the fruits. leaves). All fruits sampled did not contain seed. The dendrogram of the 55 populations of Artocarpus altilis studied, resulting from the ascending hierarchical classification, revealed three (3) groups which differ from each other by their morphological characters in the study areas.

\section{Introduction}

The breadfruit tree (Artocarpus altilis (Parkinson) Fosberg, Moraceae) is a traditional tree from Oceania with many uses ranging from construction, medicine, food to insect repellents (Jones et al., 2011). However, it is mainly grown as a food crop for its starch and is an important component of agroforestry systems. It produces large, starch-rich fruits with high yields of minerals, carotenoids and provitamin A, compared to other important commodities such as wheat, maize and rice (Jones et al., 2010, 2013). Breadfruit has been recognized as a high potential crop to increase food security and mitigate malnutrition in 
Oceania, the Caribbean, tropical Africa and elsewhere (Adebowale et al., 2005, Omubuwajo 2007, Roberts-Nkrumah, 2009; Taylor et al., 2009; Jones et al., 2011).

Although most cultivars produce fruit from August to January, growing a variety of cultivars with various fruiting seasons could yield nutrient-rich fruits all year round (Jones et al., 2010, 2013). Since the Europeans first encountered the breadfruit in the Pacific almost 400 years ago (Markham, 1904), a small number of cultivars have been introduced in the tropics of the tropics, including the Caribbean, Africa and India (Roberts-Nkrumah 2007; Omubuwajo, 2007). The genetic diversity and importance of the breadfruit, however, remains the most important in Oceania, where the breadfruit has been domesticated (Zerega et al., 2004, 2005, 2006).

Wild relatives related to the breadfruit have been identified as $A$. camansi Blanco and $A$. mariannensis Trécul, and hybrids also exist (Zerega et al., 2004, 2005). For millennia, Pacific Islanders have selected and named hundreds of traditional cultivars based on the fruiting season, the color and texture of the flesh, the presence or absence of seeds, the flavor cooking and storage qualities and horticultural requirements (Wilder 1928; Ragone 1997). Cultivars include vegetativelypropagated seedless triploids, vegetatively or seed-propagated fertile diploids, and diploid and triploid hybrids (Ragone 2007, Zerega et al., 2004). More than 2,000 names were collected for breadcrumbs in Oceania, where the breadfruit was domesticated (Ragone, 1991). Because the names are usually based on the morphological traits of the tree and the fruit, which can be influenced by the environment across the islands (Ragone and Wiseman 2007) and because the same name can be used for different types or different names.
The breadfruit tree has been introduced in Benin from the West Indies since the period of the slave trade (FAO, 1999) and the areas of high populations are located in the South of the country taking into account the climatic requirements of the species (Tandjiékpon, 2001). Despite its great potential, the species is underutilized in Canada and is threatened with extinction in its natural environment due to unsustainable traditional farming practices, overexploitation of natural stands, and reduced rainfall.. The morphological characterization of the breadfruit tree is justified mainly by the need for a better knowledge of the diversity of this species, an essential step in its safeguarding and also constitutes an important step in the increased use of its culture.

In Benin, the scientific studies carried out so far on the breadfruit tree have evaluated neither its morphological diversity nor its genetic diversity. However, the criteria for differentiation of breadfruit individuals used have been documented (Ragone, 2009); fruit shape, fruit skin texture, fruit flesh color, leaf lobe number, degree of leaf dissection, leaf surface texture, the number of seeds, the time of fruiting.

The present study based on the idea that the morphological variability of a species depends on environmental diversity. As a result, we carried out a collection program of fruits and breadfruit leaves in areas with high populations in Benin. Morphological description consists of studying the interesting morphological descriptors and identifying among them those related to environmental factors as emphasized by Zhang (2002).

\section{Materials and Methods}

\section{Field of study}

The assessment of the morphological variability of Artocarpus altilis was made 
from data on trees from four different ecological zones: Adjohoun, Avrankou and Dangbo Communes, Department of Ouémé located in the South East of Benin and the Adja-Ouèrè Commune in the Plateau department located in the southern part. These areas constitute areas of high production of Artocarpus altilis in Benin (Figure 1).

The department of Ouémé belongs to the subequatorial region with a four seasons climate (two rainy seasons and two dry seasons). Temperatures vary little $\left(25\right.$ to $\left.30^{\circ} \mathrm{C}\right)$ with a rainfall between the 900 and $1500 \mathrm{~mm}$ isohypse. There is predominantly anthropogenic vegetation: thicket, shrubby, dense, and dominated by oil palms and grasses with some forest relics in places; grassy savannah, meadows, swampy raffia formations and some mangroves. There are ferralitic, clay-sandy soils, alluvial and colluvial hydromorphic soils (INSAE, 2014).

The Plateau Department is characterized by a Sudano-Guinean type climate with two rainy seasons with an annual height of between 800 and $1,200 \mathrm{~mm}$ in its western part and between 1,000 and $1,400 \mathrm{~mm}$ in its eastern part. The soils are of several types and are constituted by the tropical ferruginous, the ground of bar on the deep continental terminal and the very clayey soil deep and humid, fertile but often very difficult to work. The plant formations are the wooded / shrub savannah in the northern part of the department, while in the center we find the dense semi-deciduous forest. The southern part of the department consists of a bush shrub dominated by oil palms and grasses. There are also some local forest relics (INSAE, 2014).

\section{Sampling and data collection}

Morphological characterization focused on trees based on their stand, accessibility and the presence of fruit on trees. Thus, it was carried out on a total of 55 trees (23 in the Commune of Dangbo, 13 in the Commune of Adjohoun, 10 in the Commune of Avrankou and 9 in the Commune of Adja-Ouèrè.

The feet selected for the observations were marked and separated from each other by at least $50 \mathrm{~m}$ in each of the fields visited. On each foot, five (5) leaves were randomly drawn from different branches for description. Five (5) mature fruits were also collected from different branches of each foot. The majority description has been taken into account in both cases (Ragone 2009; Kouyaté et al., 2011). The leaves and fruits were harvested with pruning shears or by hand. The longitudinal section of the fruit was made immediately after picking for the appreciation of the color of the flesh and the number of seeds in the fruit. This avoids the influence of any browning on the color.

Six (6) variables were analyzed according to descriptors of breadfruit tree (Ragone, 2009). All the data were collected on each tree, during the month of June 2018 and then summed to calculate the frequencies by groups of accessions by communes. The statistical analyzes carried out therefore focused only on these frequencies from the 55 individuals. The characters were:

The shape of the fruits $(\mathrm{S}=$ Spherical, $\mathrm{O}=$ Oblong)

The texture of the fruit skin $(\mathrm{L}=$ Smooth, EF $=$ Thorny with flexible tip)

The color of the flesh of the fruit $(\mathrm{B}=$ White, $\mathrm{JC}=$ Light yellow, $\mathrm{JF}=$ Dark yellow)

The number of leaf lobes (7lob $=7$ lobes, 9lob $=9$ lobes, 11 lob = 11 lobes)

The degree of dissection of the leaves (FLDM $=$ leaves slightly dissected on the upper half, 
FMD = leaves moderately dissected on the upper half, FDP = deeply dissected leaves, FDPE = deeply dissected leaves with large spaces between the lobes)

The number of seeds ( $\mathrm{Z}=$ zero, $\mathrm{K}=1$ to $3, \mathrm{P}=$ several seeds)

\section{Statistical treatment}

The collected data was analyzed with $\mathrm{R}$ version 3.2.2 software. The variables analyzed are qualitative characters. Thus, the frequencies, the intervals (IC) at 95\% of significance and the correlations (charactercharacter) were calculated. The bilateral $\mathrm{Z}$ test was used to compare the two-to-two proportions. A Principal Component analysis was conducted to group the morphological characters of fruits and leaves and an ascending hierarchical classification was also made on the four localities to show the characteristics of the groups formed.

\section{Results and Discussion}

\section{Morphological characters}

\section{Fruit analysis}

Table 1 shows the morphological characters and the presence or absence of seeds in the fruits across the different study areas. Two forms of fruit were identified in the four study areas. These are spherical fruits and oblong fruits (Figure 2). The distribution of these two forms of fruit was not significant $(p>0.05)$ in the zones. Regarding the texture of the fruit, it can be either smooth or spiny with a flexible tip. The fruits collected at Dangbo and Avrankou were all smooth. On the other hand, respectively in Adjohoun and Adja-Ouèrè, $84.62 \%$ and $66.67 \%$ of the fruits were smooth. Spiny fruits have only been found in the Adjohoun area. The colors of the flesh of the fruits encountered change from white to light yellow then to dark yellow (Figure 3). These different colors were distributed heterogeneously among the four study areas. The dark yellow color $(33.33 \%)$ was found only on the fruits collected in Adja-Ouèrè. The collected fruits have no seeds inside all the study areas.

\section{Leaf analysis}

Table 2 shows the morphological characteristics of Artocarpus altilis leaves in the different study areas. Three types of leaves have been identified. They are 7-lobed leaves, 9-lobed leaves and 11-lobed leaves (Figure 4). The distribution of leaf lobe number was significant $(\mathrm{p}<0.05)$ in the study areas. Thus, 7-lobed leaves were predominantly represented in the communes of Avrankou (60\%) and Dangbo (56\%). On the other hand, a total absence of these types of leaves was noted in the commune of Adja-Ouèrè. The 9lobed leaves were found in all four study areas (the most represented, between $26.45 \%$ and $44.44 \%$ ). The 11-lobed leaves were present in the communes of Adja-Ouèrè (55.56\%), Adjohoun (46.15\%) and Dangbo (8.7\%) respectively, but a total absence of the latter in the Commune of Avrankou.

Regarding the degree of dissection of the leaves, it was found in the study areas, either slightly dissected leaves on the upper half, or leaves moderately dissected on the upper half, or deeply dissected leaves, or leaves deeply dissected with large spaces between the lobes. Significant differences were noted in the distribution of these variables in the four communes $(\mathrm{p}<0.05)$.

The deeply dissected leaves were present and unevenly distributed in all study areas. On the other hand, leaves moderately dissected on the upper half were only present in Adjohoun commune with a proportion of $15.38 \%$ and totally absent in the other study communes. As 
for the slightly dissected leaves on the upper half, they were met only in the municipalities of Avrankou (60\%) and Adja-Ouèrè (33.33\%). The deeply dissected leaves with large spaces between the lobes were found only in the communes of Adja-Ouèrè (33.23\%) and Dangbo (29.09\%).

Relations between the characters studied at Artocarpus altilis

Correlation between fruit shape, texture and fruit color at Artocarpus altilis

Table 3 shows the correlation matrix between the shape, texture and color characteristics of fruit flesh in Artocarpus altilis. Few significant correlations were noted between the characters studied. The spherical shape was significantly and positively ( $p<0.05$ ) correlated with smooth texture and white color. The light yellow color was also positively and significantly correlated with the oblong shape and the smooth texture. Correlation coefficients were high and close to unity.

\section{Correlation between Leaf Characteristics at Artocarpus altilis}

Table 4 shows the correlation matrix between leaf characteristics in Artocarpus altilis. Only one significant correlation was noted between the characters studied. This is the deeply dissected leaf trait (FPD) that was significantly and positively ( $\mathrm{p}<0.05)$ correlated with the 9-lobed leaf (9lob). The correlation coefficient was high and close to unity.

\section{Correlation (PCA) between the morphological characters of fruit and leaf at Artocarpus altilis}

Principal component analysis identifies two axes accounting for $86.44 \%$ of the variability observed (Figure 5). Axis 1 (60.92\%) contrasts the oblong shape of the fruit $(\mathrm{O})$, the deeply dissected leaves (FDP), the light yellow color of the fruit flesh (JC), the 9 lobes leaves (9lob),

The white color (B) of the fruit flesh, the smooth texture of the fruit skin (L), the spherical shape of the fruit (S), the deeply dissected leaves with large spaces between the lobes (FDPE) and the leaves 7 lobes (7lob) with moderately dissected leaves on the upper half (FMD), 11 lobes leaves (11lob), the thorny texture with flexible tip of the skin of the fruit (EF) and the dark yellow color of the fruit flesh (JF). Axis $2(25.52 \%)$ is explanatory of slightly dissected leaves on the upper half (FLDM).

\section{Provenance classification according to the characteristics studied}

The dendrogram resulting from the ascending hierarchical classification made from the characteristics of fruits and leaves of Artocarpus altilis observed in Benin in four different provenances, showed three groups (Figure 6).

A first group (G1) consisted of the single Dangbo provenance, which is characterized by oblong (O) and spherical (S) fruit populations with smooth texture (L), whose flesh colors vary between white and white. (B) and light yellow (JC) with 9 lobes (9lob) and 7 lobes (7lob) leaves, deeply dissected leaves (FDP) and deeply dissected leaves with large spaces between lobes (FDPE).

A second group (G2) represented by the provenances of Adjohoun and Adja-Ouèrè grouping populations which are differentiated from the others by the presence of characters such as fruits with thorny texture with flexible tip (EF) with dark yellow color of fruit flesh (JF) and 11 lobes leaves (11lob). 
Fig.1 Geographical location of the study areas

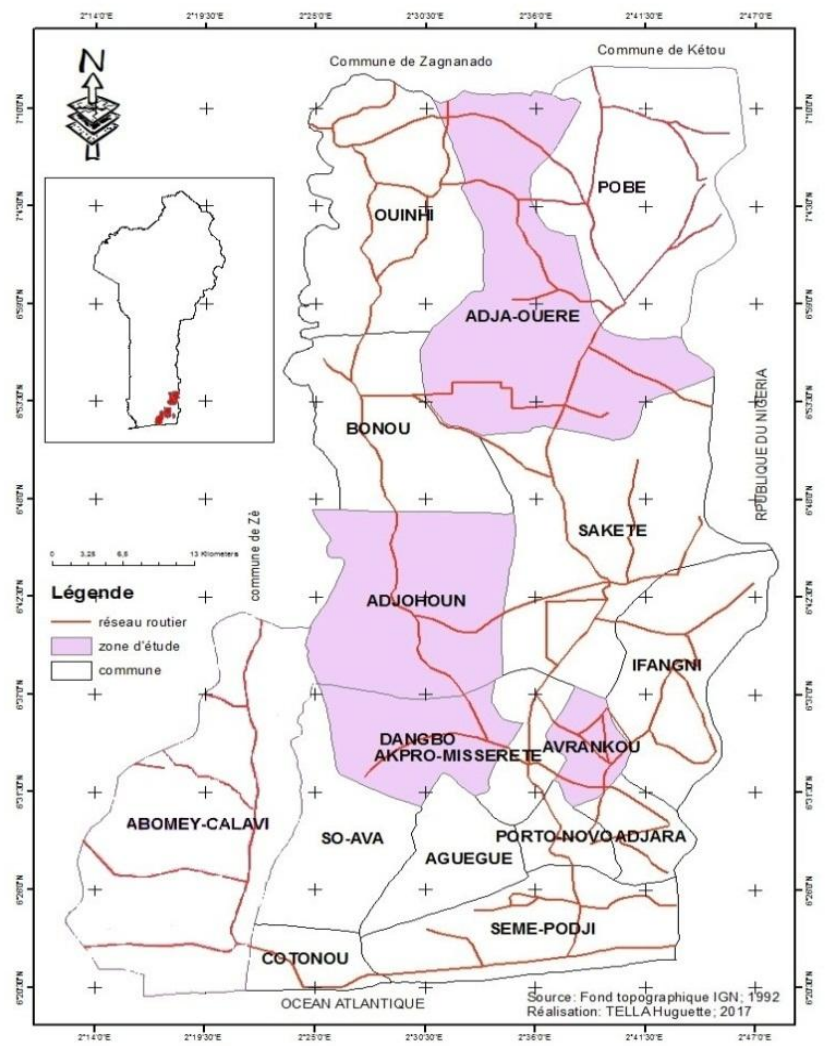

Fig.2 Categories of breadfruit shapes encountered

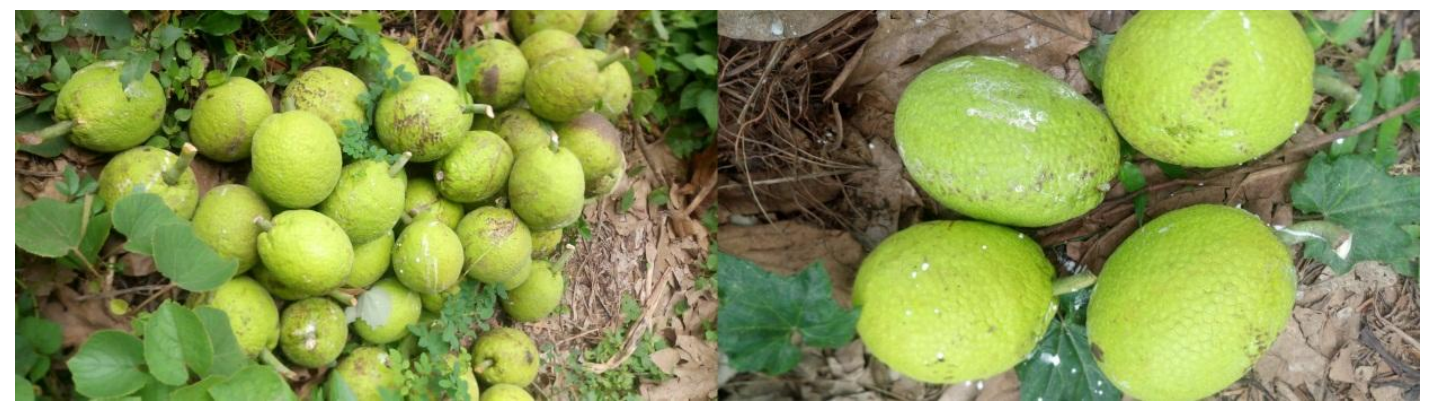

Fig.3 Longitudinal sections of breadfruit showing the color of the flesh (Photos)

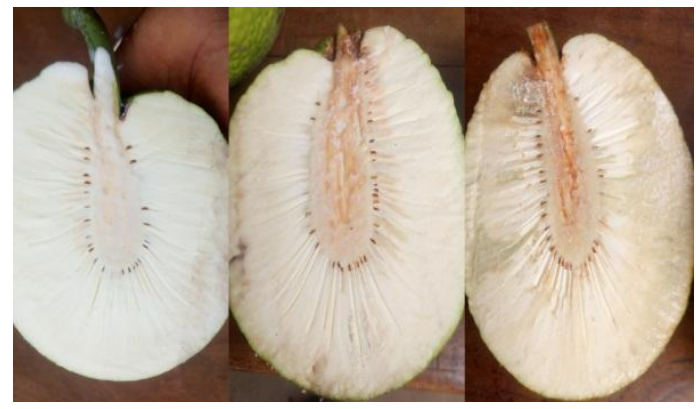


Fig.4 Artocarpus altilis leaf shape categories encountered

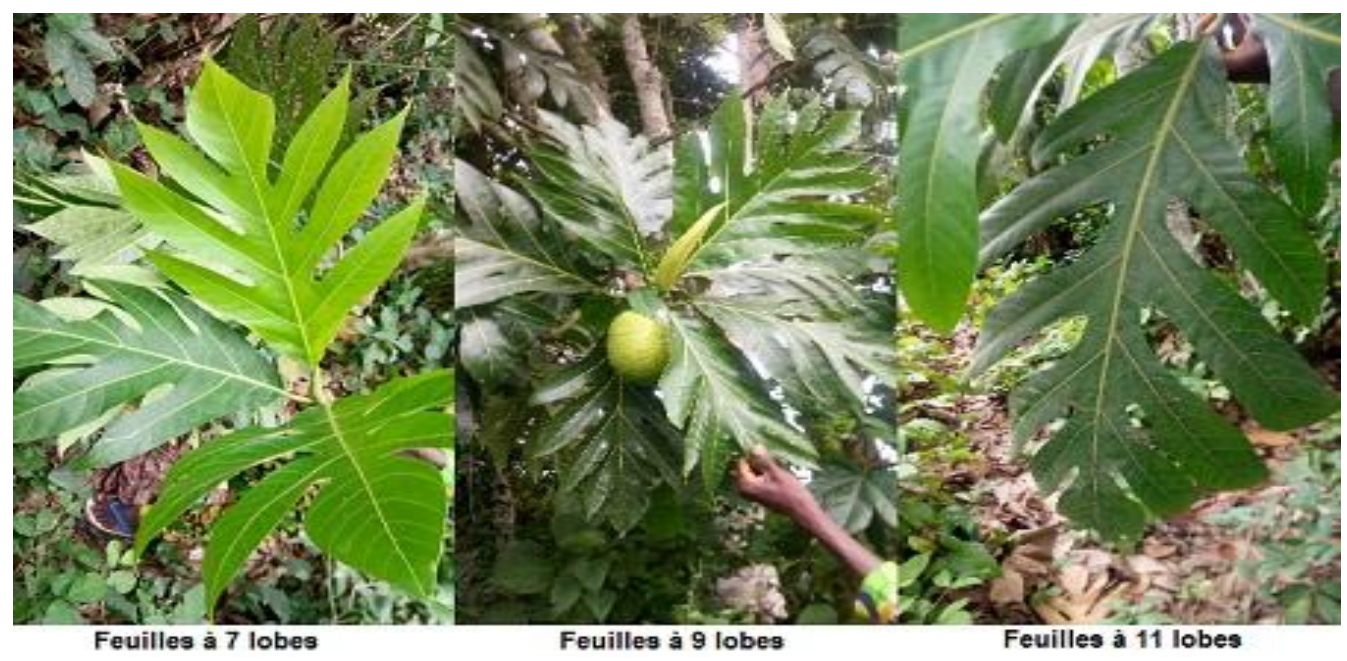

Fig.5 Correlation circle (PCA) made from the morphological characters of the fruit and leaf of Artocarpus altilis

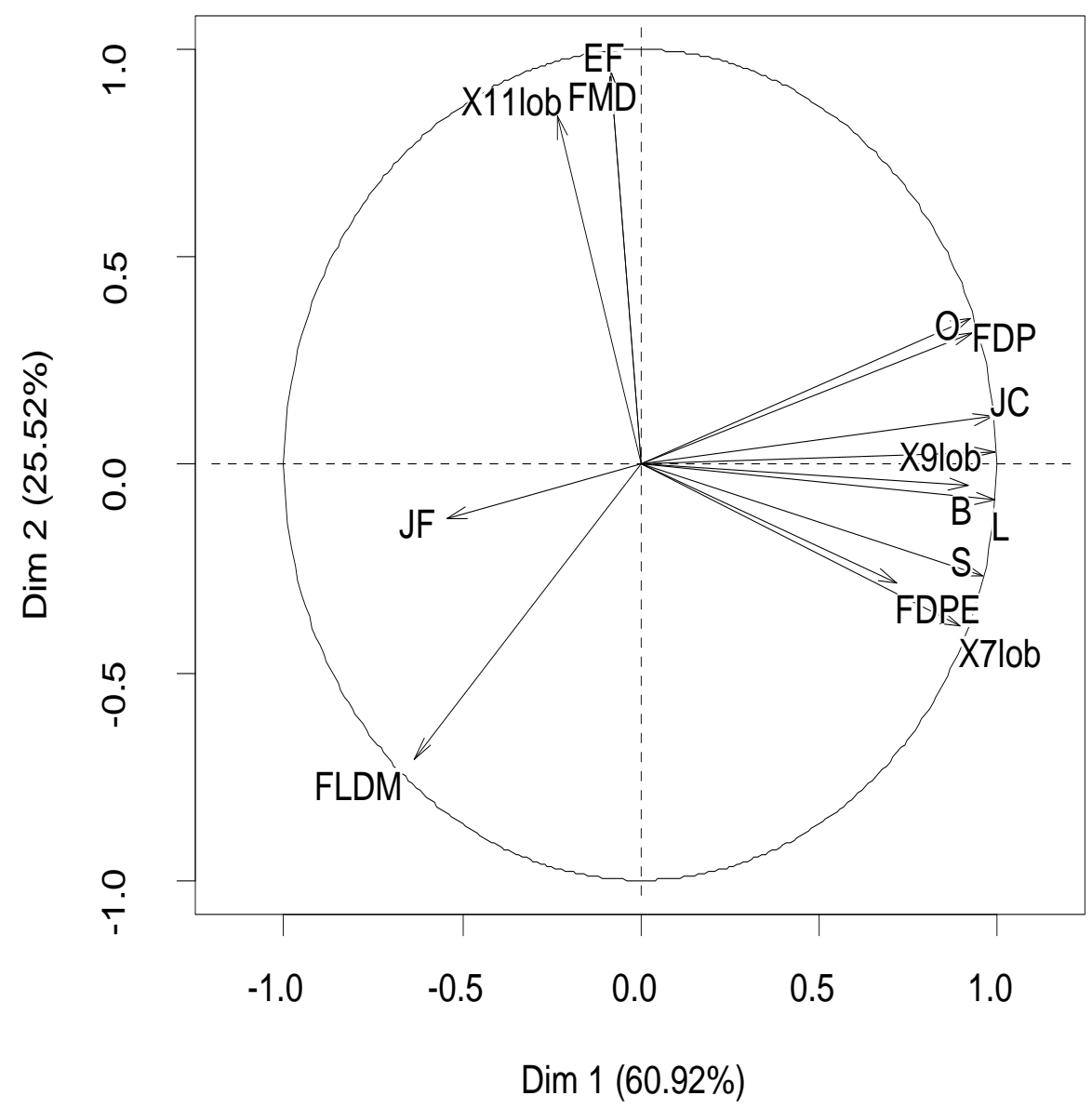


Fig.6 Ascending hierarchical classification of four localities, made from the study of morphological characters of the leaf and fruit of Artocarpus altilis in Benin

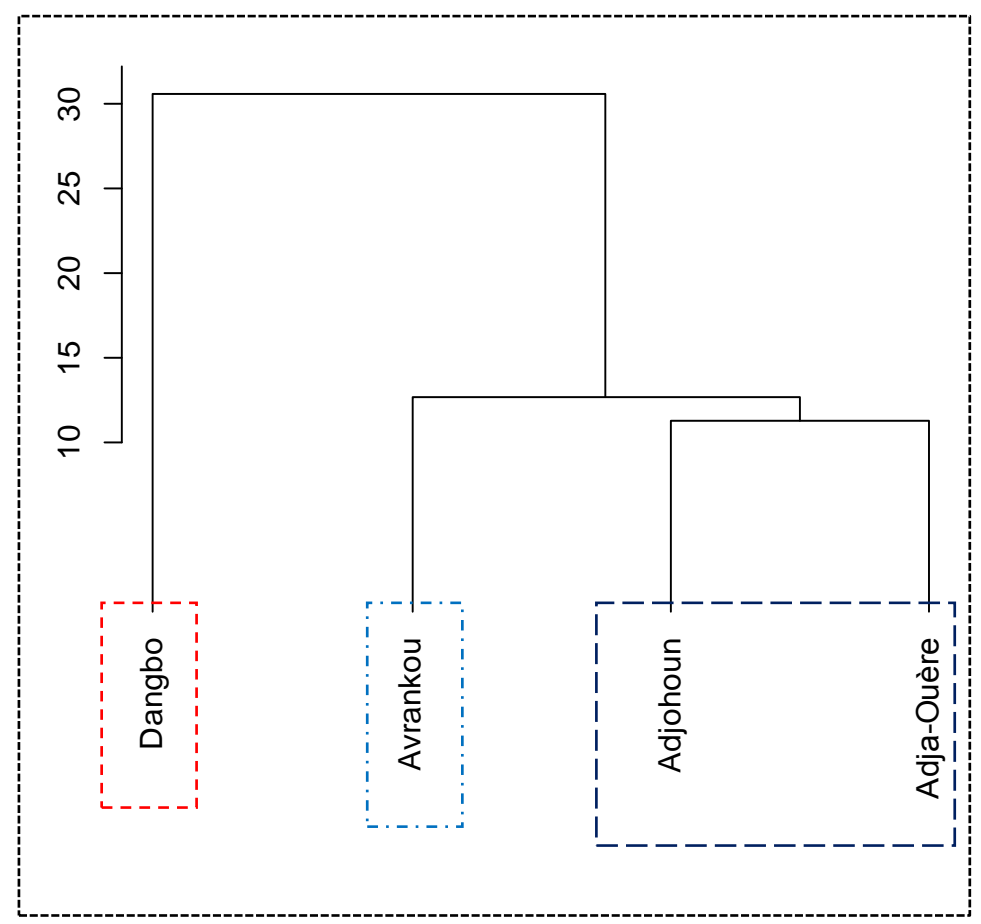

Table.1 Descriptive statistics of the shape, texture, color and number of breadfruit seeds in the study areas

\begin{tabular}{|l|c|c|c|c|c|c|c|c|}
\hline \multirow{2}{*}{ Caractères } & \multicolumn{2}{|c|}{ Dangbo (23) } & \multicolumn{2}{c|}{ Adjohoun (13) } & \multicolumn{2}{c|}{ Avrankou (10) } & \multicolumn{2}{c|}{ Adja-Ouèrè (9) } \\
\cline { 2 - 10 } & $\%$ & IC & $\%$ & IC & $\%$ & IC & $\%$ & IC \\
\hline S & $52,17 \mathrm{a}$ & 20,415 & $38,46 \mathrm{a}$ & 26,447 & $60,00 \mathrm{a}$ & 30,364 & $44,44 \mathrm{a}$ & 32,464 \\
\hline $\mathbf{O}$ & $47,83 \mathrm{a}$ & 20,415 & $61,54 \mathrm{a}$ & 26,447 & $40,00 \mathrm{a}$ & 30,364 & $55,56 \mathrm{a}$ & 32,464 \\
\hline $\mathbf{L}$ & $100 \mathrm{a}$ & 0,00 & $84,62 \mathrm{~b}$ & 19,613 & $100 \mathrm{a}$ & 0,00 & $66,67 \mathrm{~b}$ & 30,798 \\
\hline $\mathbf{E F}$ & $0,00 \mathrm{a}$ & 0,00 & $15,38 \mathrm{a}$ & 19,613 & $0,00 \mathrm{a}$ & 0,00 & $0,00 \mathrm{a}$ & 0,00 \\
\hline $\mathbf{B}$ & $34,78 \mathrm{a}$ & 19,465 & $30,77 \mathrm{a}$ & 25,09 & $40,00 \mathrm{a}$ & 30,364 & $0,00 \mathrm{~b}$ & 0,00 \\
\hline JC & $65,22 \mathrm{a}$ & 19,465 & $69,23 \mathrm{a}$ & 25,09 & $60,00 \mathrm{a}$ & 30,364 & $66,67 \mathrm{a}$ & 30,798 \\
\hline JF & $0,00 \mathrm{~b}$ & 0,00 & $0,00 \mathrm{~b}$ & 0,00 & $0,00 \mathrm{~b}$ & 0,00 & $33,33 \mathrm{a}$ & 30,8 \\
\hline $\mathbf{Z}$ & 100 & 0,00 & 100 & 0,00 & 100 & 0,00 & 100 & 0,00 \\
\hline
\end{tabular}

$\%$ : percentage; IC: confidence interval. The assigned proportions of the different letters differ significantly at the 5\% threshold. S: spherical; O: oblong; L: smooth; EF: thorny with flexible tip; B: white; JC: light yellow; JF: dark yellow; Z: zero. 
Table.2 Descriptive statistics of leaf characteristics in Artocarpus altilis in the study areas

\begin{tabular}{|l|c|c|c|c|c|c|c|c|}
\hline \multirow{2}{*}{ Caractères } & \multicolumn{2}{|c|}{ Dangbo (23) } & \multicolumn{2}{c|}{ Adjohoun (13) } & \multicolumn{2}{c|}{ Avrankou (10) } & \multicolumn{2}{c|}{ Adja-Ouèrè (9) } \\
\cline { 2 - 9 } & $\%$ & IC & $\%$ & IC & $\%$ & IC & $\%$ & IC \\
\hline 7lob & $56,52 \mathrm{a}$ & 20,26 & $15,38 \mathrm{~b}$ & 19,61 & $60,00 \mathrm{a}$ & 30,36 & $0,00 \mathrm{~b}$ & 0,00 \\
\hline 9lob & $34,78 \mathrm{a}$ & 19,47 & $38,46 \mathrm{a}$ & 26,45 & $40,00 \mathrm{a}$ & 30,36 & $44,44 \mathrm{a}$ & 32,46 \\
\hline 11lob & $8,7 \mathrm{~b}$ & 11,52 & $46,15 \mathrm{a}$ & 27,1 & $0,00 \mathrm{c}$ & 0,00 & $55,56 \mathrm{a}$ & 32,46 \\
\hline FLDM & $0,00 \mathrm{~b}$ & 0,00 & $0,00 \mathrm{~b}$ & 0,00 & $60,00 \mathrm{a}$ & 30,36 & $33,33 \mathrm{a}$ & 30,8 \\
\hline FMD & $0,00 \mathrm{a}$ & 0,00 & $15,38 \mathrm{a}$ & 19,61 & $0,00 \mathrm{a}$ & 0,00 & $0,00 \mathrm{a}$ & 0,00 \\
\hline FDP & $73,91 \mathrm{a}$ & 17,95 & $84,62 \mathrm{a}$ & 19,61 & $40,00 \mathrm{a}$ & 30,36 & $66,67 \mathrm{a}$ & 30,8 \\
\hline FDPE & $26,09 \mathrm{a}$ & 17,95 & $0,00 \mathrm{~b}$ & 0,00 & $0,00 \mathrm{~b}$ & 0,00 & $33,33 \mathrm{a}$ & 30,8 \\
\hline
\end{tabular}

$\%$ : percentage; IC: confidence interval. The assigned proportions of the different letters differ significantly at the 5\% threshold. 7lob: 7 lobes; 9lob: 9 lobes; 11lob: 11 lobes; FLDM: leaves slightly dissected on the upper half; FMD: leaves moderately dissected on the upper half; FDP: deeply dissected leaves; FDPE: deeply dissected leaves with large spaces between the lobes.

Table.3 Correlation matrix between the characters form, texture and color of the fruit at Artocarpus altilis

\begin{tabular}{|c|c|c|c|c|c|c|c|}
\hline & $\mathrm{S}$ & 0 & $\mathrm{~L}$ & EF & B & $\mathrm{JC}$ & Jlk \\
\hline$S$ & 1 & & & & & & \\
\hline 0 & $0,79^{\mathrm{NS}}$ & 1 & & & & & \\
\hline $\mathrm{L}$ & 0,98* & $0,88^{\mathrm{NS}}$ & 1 & & & & \\
\hline EF & $-0,33^{\mathrm{NS}}$ & $0,21^{\mathrm{NS}}$ & $-0,14^{\mathrm{NS}}$ & 1 & & & \\
\hline B & $0,97^{*}$ & $0,78^{\mathrm{NS}}$ & $0,94^{\mathrm{NS}}$ & $0,00^{\mathrm{NS}}$ & 1 & & \\
\hline $\mathrm{JC}$ & $0,92^{\mathrm{NS}}$ & $0,97 *$ & $0,97 *$ & $0,00^{\mathrm{NS}}$ & $0,87^{\mathrm{NS}}$ & 1 & \\
\hline $\mathrm{JF}$ & $-0,51^{\mathrm{NS}}$ & $-0,42^{N S}$ & $-0,6^{\mathrm{NS}}$ & $-0,00^{\mathrm{NS}}$ & $-0,47^{N S}$ & $-0,47^{\mathrm{NS}}$ & 1 \\
\hline
\end{tabular}

NS: not significant; $*$ p $<0.05$

Table.4 Correlation matrix between leaf characteristics in Artocarpus altilis

\begin{tabular}{|c|c|c|c|c|c|c|c|}
\hline & $71 \mathrm{ob}$ & 910b & 1110b & FLDM & FIMID & FDP & FDPE \\
\hline 3lob & 1 & & & & & & \\
\hline 4lob & $0,85^{\mathrm{NS}}$ & 1 & & & & & \\
\hline 5lob & $-0,64^{\mathrm{NS}}$ & $-0,14^{\mathrm{NS}}$ & 1 & & & & \\
\hline FLDM & $-0,23^{\mathrm{NS}}$ & $-0,69^{\mathrm{NS}}$ & $--0,60^{\mathrm{NS}}$ & 1 & & & \\
\hline FMD & $0,68^{\mathrm{NS}}$ & $-0,09^{\mathrm{NS}}$ & $0,67^{\mathrm{NS}}$ & $-0,52^{\mathrm{NS}}$ & 1 & & \\
\hline FDP & $0,68^{\mathrm{NS}}$ & $\mathbf{0 , 9 6 *}$ & $0,14^{\mathrm{NS}}$ & $-0,87^{\mathrm{NS}}$ & $0,17^{\mathrm{NS}}$ & 1 & \\
\hline FDPE & $0,62^{\mathrm{NS}}$ & $0,78^{\mathrm{NS}}$ & $0,09^{\mathrm{NS}}$ & $-0,46^{\mathrm{NS}}$ & $-0,52^{N S}$ & $0,69^{\mathrm{NS}}$ & 1 \\
\hline
\end{tabular}

NS: not significant; *: $\mathrm{p}<0.05$ 
A third group (G3) represented by the sole origin of Avrankou with populations that are differentiated from others only by slightly dissected leaves on the upper half (FLDM). Figure 6 illustrates the ascending hierarchical classification of four localities, based on the study of morphological characters of the leaf and fruit of Artocarpus altilis in Benin.

The different fruit shapes found in all the study areas showed the existence of two types of breadfruit forms: the spherical shape and the oblong shape. This observation is consistent with the results of the work of Ragone (2009), who also found these two types of breadfruit form in the areas of Malaysia, the South Pacific Islands, West Africa and South Africa. In the Caribbean.

Smooth texture was found in all study areas, in contrast to the spiky, flexible-tipped texture that was only found in the Adjohoun Commune. This can be explained by the effect of climatic conditions on the species and / or the varietal selectivity of a single species that has persisted thereafter in the different study areas as underlined by Ksontini (1996). Thus, we note a transition from the thorny skin to a smooth skin of the fruit. This result corroborates that of Jones $e t$ al., (2012) who had shown that this transition appeared during the domestication of the breadfruit and seemed to have been chosen more as the fruit crop moved to Eastern Polynesia. Variation in the color of the fruit flesh (from white to light yellow then to dark yellow) is an explanation of the starch content in the fruit; which is common in some other staple crops such as rice as Sweeney et al., (2007).

Indeed, after the initial domestication of Artocarpus altilis, the first cultivars accompanied the pioneers when they colonized the Pacific islands (Zerega et al., 2004, 2006). These first servants from New
Guinea had traveled to the rest of Melanesia and then to Polynesia (Zerega et al., 2004). During this migration, the process of domestication continued and several distinct characters appeared in the morphology of the breadfruit. The most documented of these changes was the reduction in the number of seeds as this crop moved eastward (Ragone, 2001). Seeded cultivars found in Melanesia gave way to seedless triploid cultivars in West Polynesia, and almost exclusively to seedless triploid cultivars in French Polynesia; which indicates a strong selection pressure for the absence of seeds. (Ragone 2001; Zerega et al., 2006). It was the same for the introduction in West Africa and more particularly in Benin where the introduced varieties would be seedless triploids; which is confirmed here in the case of our study. The absence of seeds in the fruits encountered in all the study areas can be explained by this migration.

The breadfruit trees we sampled had (7 lobes, 9 lobes, and 11lobes leaves.) These results are corroborated by the results reported by Abimbola (2010) and Agudo (2014) who found five 5 to 11 lobes per sheet and those of DAG (2017), which recorded 8 to 12 lobes per leaf in French Polynesia, the original region of the breadfruit The uneven distribution of these types of leaves across the different study areas may be related to the sensitivity of these descriptors to environmental factors. The same is true for the dissection degree characters of leaves where the degree of dissection varies according to soil fertility and breadfruit culture conditions (Deivani and Subhash, 2010) According to Ragone (2006), many seedless Artocarpus altilis triploids of Polynesian varieties were genetically identical, but morphologically distinct. Seedless, according to the same author tend not to grow well in difficult climatic conditions, while seeded and hybrid varieties are better suited to these conditions. The 
species of Artocarpus altilis encountered in our study were only seedless varieties. It may well be triploids as pointed out by the author, who, because of the difficult conditions have developed new characters.

The correlation analysis between the characters of the fruits studied showed that the spherical shape is closely related to the white color of the flesh and the smooth texture of the fruit. This type of fruit is similar to "Maohi", the most common variety in Tahiti that is still spherical in shape, smooth in texture with a white flesh color and seedless (DAG, 2017). These may be the first triploids that would have returned to West Africa and Benin, thanks to migration as emphasized by Zerega et al., (2004, 2006) who had demonstrated that breadfruit is most often propagated asexually, and its spread and domestication are closely related to human migration patterns. Over several generations, repeated vegetative selection like this can lead to dramatic morphological changes in the crop, so that they no longer resemble their wild spawners; hence the second correlation observed between fruits where the light yellow color of the flesh is closely related to the oblong shape and smooth texture of the fruit. The light yellow color of the flesh can be explained by the decrease in the starch content, which in the meantime was high, conferred white color on the flesh of the fruit (Sweeney et al., 2007). These morphological changes often referred to as crop domestication syndrome, typically include traits that make the crop more productive or culturally appropriate (Hammer 1984). In the case of the breadfruit, this process seems to have resulted in strong selection pressure, which explains the high level of morphological diversity observed in the different regions.

Only one correlation was revealed at the leaf level; this was the deeply dissected leaf trait
(FPD) that is closely related to the 9 lobes leaf trait (9lob). The 9 lobes leaves were usually those that were deeply dissected. This result differs from that of Ragone (2006) who showed that the pattern of leaf lobes varied among cultivars. This difference can be explained by the effect of environmental factors on the species; the better the crop conditions, the better the leaves are developed with the appearance of several lobes.

The correlation analysis between the characters of the fruit and the leaf showed three groups (Figure 6). A first group (G1) that gathers characters such as the oblong shape of the fruit $(\mathrm{O})$, the deeply dissected leaves (FDP), the light yellow color of the fruit flesh (JC), the 9 lobes leaves (9lob), the white color (B) of the fruit flesh, the smooth texture of the skin of the fruit (L), the spherical shape of the fruit (S), the deeply dissected leaves with large spaces between the lobes (EPDF) and the 7 lobes leaves (7lob); a second group (G2) which differs from the first by moderately dissected leaves on the upper half (FMD), 11 lobes leaves (11lob), spiny texture with flexible fruit-skin tip (FE), dark yellow color of the flesh of the fruit (JF) and a third group (G3) which differs from the first two groups by a single character, leaves slightly dissected on the upper half (FLDM).

The established dendrogram (Figure 6) allowed us to know the respective provenances of these different groups. Thus the first group (G1) comes from Dangbo, the second group of Adjohoun and Adja-Ouèrè and the third group (G3) of Avrankou. The differentiation observed at the trait level is either related to the sensitivity of these descriptors to environmental factors, or to human pressure that would have made its own selection of plant material. These groups are of great interest for future genetic improvement schemes (intergroup genetic 
material exchange) of Artocarpus altilis. Also, they present complementary characters. This is instructive because a similar finding was also made during the work on Robusta coffee trees (Dussert et al., 1999). This allowed for the use of a recurrent and recurrent type selection scheme, currently applied to the improvement of Robusta coffee, which is carried out in coffee growing in Côte d'Ivoire (Montagnon, 2000).

The evaluation of the morphological variability of the breadfruit (Artocarpus altilis) carried out contributes to improving the knowledge of the morphological descriptors and the plant material present in various localities of the sampled agroecological zones. This evaluation, which focused on the morphological characteristics of Artocarpus altilis in Benin, revealed: a polymorphism of fruit shape, texture of the skin of the fruit, color of the flesh of the fruit, number of leaf lobes and degree of leaf dissection and three (3) groups with often complementary characteristics. From all sources, the variability observed was not the same according to the descriptors. There may be different varieties of Artocarpus altilis in Benin. Each breadfruit tree provenance group highlighted in our study could be considered to have similar genotypes for the characteristics studied. Such a work of morphological characterization of the breadfruit tree constitutes an essential link of the varietal selection in order to identify individuals responding to the concerns of the peasant communities and to domestication.

\section{References}

Abimbola O. O., Roseline F., Olubukola I., Adebayo O. A. B. \& Peter D., 2010. Potential of breadfruit (Artocarpus altilis) anecologically forest based feed resource in rabbit nutrition. Tropical and Subtropical Agroecosystems, 12: 99-108.

Adebowale K. O., Olu-Oqolabi B. I., Olawumi E. K. \& Lawal O. S., 2005. Functional properties of native, physically and chemically modified breadfruit (Artocarpus altilis) starch. Ind. CropsProd. 21: 343-351

Agudo D. P. E., 2014. Artocarpus altilis: Domestication et usages. Master 1 BVT; Ethnobotanique et Interactions Bioculturelles: FMOB215, Doyle Mckey, 6p.

Berthaud J., 1986. Les ressources génétiques pour l'amélioration des caféiers africains diploïdes. Evaluation de la richesse génétique des populations sylvestres et de ses mécanismes organisateurs. Conséquences pour l'application, Paris, France, ORSTOM, $379 \mathrm{p}$.

DAG, 2017. Fiche Technique: Le uru ou arbre à pain. TAHITI, Polynésie française: Ministère de l'agriculture, de l'élevage et de la forêt, département du développement de l'agriculture (DAG), $4 p$.

Deivani S. and Subhash J. B., 2010. Breadfruit (Artocarpus altilis Fosb.) An underutilized and neglected fruit plant species. Middle-East Journal of Scientific Research 6 (5): 418-428.

Dussert D., Lasherme P., Anthony F., Montagnon C., Trouslot P., Combes M.C., Berthaud J., Noirot M. et Hamon S., 1999: Le caféier, Coffeacanephora, in: P. Hamon, M. Seguin, X. Perrier et J.C. Glaszmann (Eds): Diversité génétique des plantes tropicales cultuvées. CIRAD Montpellier: 175 194.

FAO, 1999. Vers une définition harmonisée des Produits Forestiers Non ligneux Unasylva 50(198), 63-64.

Fownes J.H., Raynor W.C., 1991. Seasonality and yield of breadfruit cultivars in the 
indigenous agroforestry system of Pohnpei, Federated States of Micronesia. Trop Ag (Trinidad) 70 (2):103-9.

Hammer K., 1984. The domestication syndrome. Kulturpflanze 32: 11-34

Jones A.M.P., Baker R., Ragone D., Murch S.J., 2013. Identification of pro-vitamin A carotenoid rich cultivars of breadfruit (Artocarpus, Moraceae). J Food Compos Anal 31(1): 51-61. doi.org/10.1016/j.jfca.2013.03.003

Jones A.M.P., Murch S.J., Ragone D., 2010. Diversity of breadfruit (Artocarpus altilis, Moraceae) seasonality: a resource for year-round nutrition. Econ Bot 64(4):340-351.

Jones A.M.P., Murch S.J., Wiseman J., Ragone D., 2012.Morphological diversity in breadfruit (Artocarpus, Moraceae): Insights into domestication, conservation and cultivar identification. Genet Resour Crop Evol (2013) 60, 175-192. DOI 10.1007/s10722-0129824-8

Jones A.M.P., Ragone D., Aiona K., Lane W.A., Murch S.J., 2011. Nutritional and morphological diversity of breadfruit (Artocarpus, Moraceae): Identification of elite cultivars for food security. J Food Compos Anal 24:1091-1102. doi: 10.1016/j.jfca.2011.04.002

Kouyaté A. M., Decaluwé E., Guindo F., Diawara H., Diarra I., N'diaye I., Vandamme P., 2011. Variabilité morphologique du baobab (Adansonia digitata L.) au Mali. Fruits, 66: 247255. DOI: $10.1051 /$ fruits/2011032.

Leakey, CLA (1977) Breadfruit Reconnaissance Study in the Caribbean Region. CIAT/ Inter American Development Bank.

Markham C., 1904.The Voyages of Pedro Fernandez de Quiros, 1595-1606.Vol. I. Hakluyt Society, London.
Montagnon C., 2000. Optimisation des gains génétiques dans le schéma de sélection récurrente réciproque de Coffeacanephora Pierre. Thèse de Doctorat de l'Ecole Supérieur Agronomique de Montpellier, 109 pp.

Nacitas J., 2012. Composition du fruit à pain récolté sur un territoire contrasté structure, propriétés et aptitudes technologiques de son amidon, Thèse unique, Université des Antilles et de la Guyane (2012) 17p.

Omubuwajo T.O., 2007. Breadfruit as a key component of sustainable livelihoods in Nigeria: prospects, opportunities and challenges. Acta Hortic (757):121-124.

Ragone D., 1991.Collection, Establishment and Evaluation of a Germplasm Collection of Pacific Island Breadfruit.Dissertation, University of Hawaii.

Ragone D., 1997. Breadfruit: Artocarpus altilis (Parkinson) Fosberg. Promoting the conservation and use of underutilized and neglected crops 10. IPGRI, Inter Plant Genetic Resources Inst, Rome, Italy.

Ragone D., 2001.Chromosome numbers and pollen stainability of three species of Pacific Island breadfruit (Artocarpus, Moraceae).Am J Bot 88(4):693-696.

Ragone D., 2006.Artocarpus altilis (breadfruit), ver. 2.1. In: Elevitch, C.R. (ed.). Species Profiles for Pacific Island Agroforestry.Permanent Agriculture Resources (PAR), Hōlualoa, Hawai'i. <http://www.traditionaltree.org $>$.

Ragone D., 2007. Breadfruit: Diversity, conservation, and potential. ActaHortic 757:19-30.

Ragone D., 2009. Profil de production et de commercialisation agricoles et des forêts pour l'arbre à pain (Artocarpus altilis) Pp. 221 dans Elvitch CR, rédacteur en chef., Ed. Les cultures spéciales pour les îles 
du Pacifique Agroforesterie. Ressources agricoles permanents (PAR), Holualoa, Hawai'i: Disponible à http://agroforestry.net/scps.

Ragone D., Wiseman J., 2007. Developing and applying descriptors for breadfruit germplasm. ActaHortic 757:71-80.

Roberts-Nkrumah L.B., 2007. An overview of breadfruit (Artocarpus altilis) in the Caribbean. ActaHortic 757:51-60.

Sweeney M.T., Thomson M.J., Cho Y.G., Park Y.J., Williamson S.H., Bustamante C.D., McCouch S.R., 2007.Global dissemination of a single mutation conferring white pericarp in rice. PLoS Genet 3:e133.

Tandjiekpon A., 2001. Diagnostic des espèces forestières comestibles à grande consommation au Sud-Benin: résultats préliminaires, In: B.P. Agbo, D.Y. Arodokoun, K. Aïhou and A. Matthess (eds.), Recherche Agricole pour le Développement. Actes de l'Atelier Scientifique-Niaouli, p.295-304

Taylor M., Kete T., Tuia V., 2009. Underutilized species in the Pacific: An untapped source of nutritional and economic wealth. ActaHortic 806:235240.

Wilder, G.P., 1928. Breadfruit of Tahiti.B.P. Bishop Museum.Bulletin 50, Honolulu.

Zerega N.J.C., Ragone D., Motley T.J., 2004. Complex origins of breadfruit (Artocarpus altilis, Moraceae): Implications for human migrations in Oceania. Am J Bot 91(5):760-6.

Zerega N.J.C., Ragone D., Motley T.J., 2005. Systematics and species limits of breadfruit (Artocarpus, Moraceae). Sys Bot 30:603-15.

Zerega N.J.C., Ragone D., Motley T.J., 2006. Breadfruit origins, diversity, and human-facilitated distribution. In: Motley T, Zerega N, Ross H (eds) Darwin's Harvest: New Approaches to the Origins, Evolution, and Conservation of Crops. Columbia University Press, New York, pp 213238

Zhang D., 2002. Marqueurs moléculaires; Outils de choix pour le génotypage des plantes, in: Les apports de la biologie moléculaire en arboriculture fruitière, $12^{\mathrm{e}}$ colloque sur les recherches fruitières, INRA, Bordeaux, France.

\section{How to cite this article:}

Karl Tamègnon Assogba, Célestin C.K. Tchekessi, Roseline Bleoussi, Pivot S.A. Sachi, Anayce A. Djogbe, Jultesse S.B. Banon, Innocent Bokossa Yaou and Paulin Azokpota. 2019. Morphological Variability of Breadfruit Tree (Artocarpus altilis) in Benin. Int.J.Curr.Microbiol.App.Sci. 8(01): 2936-2949. doi: https://doi.org/10.20546/ijcmas.2019.801.312 